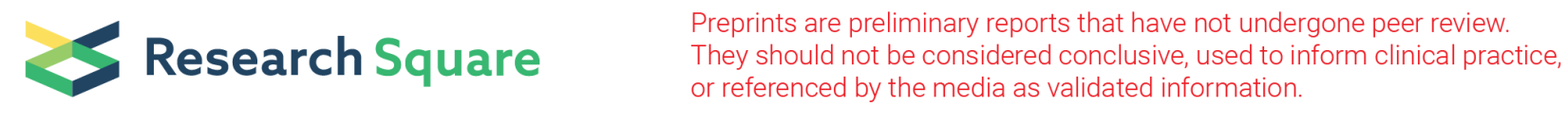

\title{
RF-EMF Exposure Emitted From Mobile/cellular Phone and Risk of Glioma, Meningioma and Acoustic Neuroma: A Meta-analysis
}

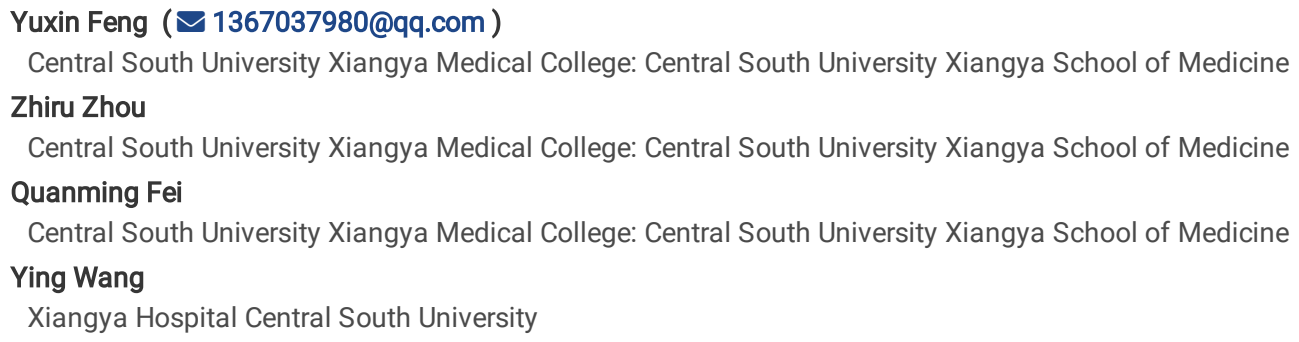




\section{Abstract}

Introduction

To evaluate the association between mobile/cellular phone use and risk of three intracranial tumors (glioma, meningioma and acoustic neuroma) based on case-control studies through pooling the published data .

Methods

We conducted a systematic literature search in databases including PubMed, EMBASE, and the Cochrane Library up to September 2021. The primary outcome was the risk of tumors by mobile/cellular phone use, which was measured by pooling each odds ratio (OR) and its $95 \%$ confidence interval (Cl). The randomor fixed-effects model was applied to combine the results depending on the heterogeneity of the analysis.

Results

We ultimately included 6 articles for glioma, 6 articles for meningioma and 8 for acoustic neuroma from 1999 to 2015 . There was no significant association between mobile/cellular phone use and risk of glioma (OR, 0.98; 95\% Cl, 0.81-1.17; $\left.\left.\right|^{2}=76.9 \%, p=0.001\right)$ and acoustic neuroma (OR, 0.98; 95\% Cl, 0.76-1.25; $\left.I^{2}=60.7 \%, p=0.013\right)$. And no statistical significance was observed between any subgroup of duration of use and these two type of cancer. Howerver, mobile phone use was associated with decrease the risk of meningioma, especially when the time since first use was between 0-5 years (OR, 0.83; $95 \% \mathrm{Cl}$, 0.76-0.90; $\left.\mathrm{I}^{2}=39.5 \%, \mathrm{p}=0.142\right)$ and $5-10$ years $\left(\mathrm{OR}, 0.83 ; 95 \% \mathrm{Cl}, 0.75-0.93 ; \mathrm{l}^{2}=32.3 \%, \mathrm{p}=0.194\right)$, while the protective effect disappeared in longer term (more than $10 / 11$ years) $\left(\mathrm{OR}, 0.91 ; 95 \% \mathrm{Cl}, 0.80-1.03 ; \mathrm{I}^{2}=0.0 \%, \mathrm{p}=0.870\right)$.

Conclusion

Evidence from our study mobile/cellular phone use may decreased risk of meningioma. Further studies are needed to explore the possible influence of longterm use of mobile phone and underlying mechanism.

\section{Introduction}

The increasing spread of radiofrequency electromagnetic fields (RF-EMF) has aroused wide concern about health care. Mobile phones are one of the most important factors that can give rise to human exposure of RF-EMF. There are some studies indicating that mobile phones or similar equipment may be factors that cause oxidative stress and even cause damage to DNA, which may lead to the development of different pathology including tumors [1, 2]. But the confidence level and specific mechanism still remain unclear, which makes it necessary to evaluate the risk of cancer. In the year of 2011, the International Agency for Research on Cancer (IARC) concluded that radiofrequency (RF) radiation from personal devices like mobile phones and other devices is classified as a Group 2B, meaning that RF-EMF is possibly carcinogenic to humans. But it is only weak mechanistic evidence that proves the relativity. As mobile phone gradually being a necessity of life, the relativity needs to be proved [3].

In summary, there are several previous studies that have discussed the association between wireless phones and tumors while concluding the opposite result. Michael Carlberg et al found relationships between exposure of mobile phone and other similar devices while Michael H.Repacholi et al have the contrary conclusion [4, 5]. Michael Carlberg and Lennart Hardell's meta-analysis of case-control studies drew the conclusion that glioma is caused by RF radiation by using the nine Bradford Hill viewpoints [4]. Also, Elisa Carvalho de Siqueira provided evidence of relation between parotid tumor and wireless phone use though presenting mild effect. However, divergence exists [5]. Michael H.Repacholi found no consistent relationship between glioma, meningioma, acoustic neuroma, or parotid gland tumors and wireless phone use in both vivo and epidemiology studies, knowing that the four tumors originate in the areas of the head that most absorb the RF energy from wireless phone [6]. In a word, inconsistency remains in the study of whether cancer is associated with wireless phone use. Besides, the duration of use is also controversial. There have been few studies highlighting the fact that long-term ( $>10$ years) wireless phone use may increase the risk of cancers like acoustic neuroma, meningioma and glioma [7, 8], according to which we divide the group of the latency time in $1-5$ years as short-term use, $\geq 10$ years as long-term use and remaining part as medium-time use.

Above all, this meta-analysis was to evaluate the relationship of glioma, meningioma, acoustic neuroma and duration of use of mobile/cellular phones in order to find supportive results.

\section{Methods}

\section{Literature review}

We searched PubMed, EMBASE, and the Cochrane Library in September 2021, using "(cordless phones OR mobile phone OR cellular phone OR electromagnetic fields OR radiofrequency electromagnetic fields) AND (glioma OR meningioma OR acoustic neuroma OR vestibular schwannoma)" as the search term. Two authors independently reviewed the articles from the search and selected articles meeting the predetermined selection criteria. Disagreements between the two authors were resolved by discussion The references of these included studies were then checked to identify additional relevant publications.

\section{Selection criteria}


The inclusion we developed and applied for data analysis are as follows:(1)Studies assessing the association between mobile/cellular phone and the three kinds of cancer.(2) Researches on humans.(3) Diseases confirmed through professional methods such as histology, imaging, and pathology.(4) Case-control design instead of cohort design.(5) Detailed data of the calculated OR value and 95\% confidence interval(Cls) or numbers of people of case and control subjects were provided.(6) If a series of studies of the same group of the same population are reported, the latest study shall be included. Exclusion criteria:(1) When including duplicate articles from previous publications, or meta-analysis, conference abstracts, letters, comments, or editorial articles, these studies are excluded.(2) Researches on parental occupational exposure and offspring cancer were excluded.(3) Articles not written in Chinese or English are also excluded.

\section{Data collection and quality assessment}

The following information was extracted from the included studies: title, first author, year of publication, countries studied, sample size, study period, phone type, age range, sex, age, adjusted OR ( $95 \% \mathrm{Cl}$ ) and adjustment factor. Newcastle - Ottawa Quality Assessment Scale (NOS) was used to evaluate the quality of articles from three perspectives of selection, comparability and exposure, with a score ranging from 0 to 9 . We also collected time since first regular use (years) and the corresponding ORs. These Articles had similar partition criterion, so we put data of same interval length into three subgroups: Long-time use ( $\geq 10 / 11$ years), Medium-time use (5-9/10 years) and Short time use (1/1.5-4/5 years).

In the subgroup analysis, if the OR value was not reported directly, the number of individuals in cases and controls were also abstracted when needed, instead of copying the adjusted OR value from the literature. If the article didn't reported the number of people who never/rarely use mobile/cellular phone, we calculated it by subtracting number of regular use from total. Additionally, when an individual study reported data on wireless phone instead of mobile phone or cellular phone, the data were not selected to ensure the accuracy. We firstly used the adjusted data if the study reported it.

\section{Main and Subgroup Analyses}

For the main analysis, in order to find the relation between RF-EMF exposure produced by mobile/cellular phone and cancer, we collected adjusted ORs to calculate the total OR value. The studies on our topic used different research methods on the length of exposure (including especially separate time periods since first use of a mobile/cellular phone), which were put into subgroup meta analyses.

For subgroup analysis of length of use for glioma, meningioma, acoustic neuroma, we set appropriate standard for selecting the referent and exposure group to guarantee the logical results. the groups with longer than about 10 years exposure selected as the long time use and never/rarely groups as referent group were put together to calculate the total OR value. In the same way, the subgroup of Medium time use (5-9/10 years) and Short time use (1/1.5-4/5 years) use for each cncer type. However, the study whose divided time periods were really disparate with others, were excluded from this subgroup.

\section{Statistical Analysis}

Microsoft Excel was used to organize the initial data, show the basic information and build a database. Adjusted ORs and numbers of individuals in every group were saved in Excel, to compute a pooled OR with its $95 \% \mathrm{Cl}$ using different methods. For the study which we collected number of individuals instead of adjusted OR, we firstly calculated OR and then calculated pooled OR with others.

In our meta-analysis, the random-effects method of DerSimonian and Laird was used when heterogeneity was present in some of the comparisons. In other cases, we used fixed-effects method (inverse variance). Heterogeneity was assessed by Chi-square based Q-test and Isquared test. If $\mathrm{P}$ value for $\mathrm{Q}$ test $<0.05$ or $I^{2}>50 \%$, heterogeneity is significant. By performing sensitivity analysis, we excluded several studies to reduce the heterogeneity as far as possible. We estimated publication bias using Begg's and Egger's test. When there is publication bias, the p-value $<0.05$. The Stata/MP 16.0 software was used for statistical analysis (StataCorp, College Station, Texas, USA).

\section{Results}

\section{Literature Search}

Totally 41478 participants including 13021 cases and 28457 controls were enrolled in the final analysis (Table1). the most common type discussed is acoustic neuromas (8 out of 17 studies, $47 \%)$, followed by meningiomas (6/17, 35\%), salivary gland tumors $(6 / 17,37 \%)$, as some of the articles discussed more than one type of cancer. The types of phones classified in the studies are mobile phones $(14 / 17,82 \%)$ and cellular phones (3/17, $18 \%)$.

\section{Quality assessment}

Table 2 shows the methodological quality assessment of the included articles using NOS. The included articles scored between 7 and 9 , with an average score of 8 . Among them, there are 7 with a score of 7,9 with a score of 8 and 1 with a score of 9 . Articles with scores less than 9 are mainly due to their poor control selection or lower comparability between the experimental group and the control group or lower response rate.

\section{Main Analysis:}

Compared with never or none, the overall use of Mobile/Cellular phones was not associated with risk of glioma in a random-effects meta-analysis of all 6 studies (OR, $\left.0.98 ; 95 \% \mathrm{Cl}, 0.81-1.17 ; \mathrm{l}^{2}=76.9 \%, \mathrm{p}=0.001\right)$. For acoustic neuroma, there's no statistical significance between them (OR, $0.98 ; 95 \% \mathrm{Cl}, 0.76-1.25$; $\left.\mathrm{I}^{2}=60.7 \%, \mathrm{p}=0.013\right)$ either. However, decreased risk of meningioma was observed:OR, $0.84 ; 95 \% \mathrm{Cl}, 0.78-0.91 ; \mathrm{l}^{2}=47.3 \%, \mathrm{p}=0.091$, which calculated with fixed effect model (Fig 2). 


\section{Subgroup Analysis}

Due to the heterogeneity and publication bias between studies, subgroup analyses were performed to evaluate the association between length of mobile/cellular phone use and specific type of cancer.

\section{Glioma}

All the included references ( 6 articles including 18 studies about length of exposure and risk of glioma) had similar basis for grouping reported time since first use of wireless phone. Two studies, from S. Lönn (2005) and L. Hardell (2015), were excluded because they demonstrated significant heterogeneity. Then we calculated OR and Cl values of L. Hardell's research (2015), and put this result (OR, 1.05; Cl: 1.05-1.47) into meta analysis. Therefore, 6 articles including 16 studies were analyzed by selecting the three groups (Short, Medium and Long) as the exposure and people never/rarely use mobile/cellular phone as referent group to calculate the pooled OR value. In the random effect models, no association between duration of use mobile/cellular phones and gliomas was found (Fig 3).

\section{Meningioma}

Subgroup analyses were performed to identify the association between duration and cancer risk. We calculated the OR and $\mathrm{Cl}$ values of two studies from E.Cardis (2010) (OR, 0.846; Cl: 0.745-0.961) and M.Carlberg (2015) (OR, 0.909; Cl: 0.778-0.963) and put them into meta-analysis. As shown in Fig 4, there were 6 articles was put into subgroup of short, medium and long time use respectively. The result from fixed effect models indicated that using mobile/cellular phones for a short or medium time ( $\leq 10$ years) could reduce the risk of meningioma (OR, $0.83 ; 95 \% \mathrm{Cl}, 0.76-0.90 ; \mathrm{I}^{2}=39.5 \%, \mathrm{p}=0.142 ; \mathrm{OR}, 0.83 ; 95 \% \mathrm{Cl}, 0.75-$ $\left.0.93 ; I^{2}=32.3 \%, p=0.194\right)$. However, the protective effect lost in the subgroup of long time use $\left(\mathrm{OR}, 0.91 ; 95 \% \mathrm{Cl}, 0.80-1.03 ; \mathrm{I}^{2}=0.0 \%, \mathrm{p}=0.870\right)$.

\section{Acoustic neuroma}

After excluding H. C. Christensen(2004) and L. Hardell(2013)'s studies in the subgroup of long time and medium time use respectively through sensitivity analysis. B. Schlehofer(2007)'s study was also excluding because of the small-sample size which led to statistical limitation. ORs and Cls of three studies including L.Klaeboe(2007)(OR, 0.52; Cl: 0.26-1.05), E. Cardis(2011) (OR, 0.85; Cl:0.72-1.01)and L. Hardell(2013) (OR, 0.88; Cl: 0.63-1.22) were calculated using numbers of individuals before pooled them into meta-analysis. Similar to glioma, no association between duration of use mobile/cellular phones and acoustic neuroma were observed in the final fixed effect model (Fig 5).

\section{Publication Bias}

Publication bias was not observed in the main and subgroup meta-analysis according to the results of Begg's test and Egger's test.

\section{Discussion}

In this meta-analysis, we found no association between mobile/cellular phone use and risk of glioma and acoustic neuroma no matter in main or subgroup analyses. For meningioma, decreased risk was observed mobile phone use was associated, especially when the time since first use was less than 10 years, while the protective effect disappeared in longer term (more than 10/11 years).

As for glioma, our result showed no association correlation between mobile phone use of any duration and glioma risk when pooled data of time since first use from 6 articles into meta-analysis, which was consistent with the previous study [26-29]. However, several research showed long-term mobile phone use may be associated with an increased risk of glioma: Yang, M., et al. (2017) reported the significant positive association between long-term mobile phone use (minimum, 10 years) and glioma $(\mathrm{OR}=1.44 ; 95 \% \mathrm{Cl}=1.08-1.91)$ [29], Y. Wang (2016), also found an association between mobile phone use more than 5 years and glioma risk $\left(\mathrm{OR}=1.35 ; 95 \% \mathrm{Cl}=1.09-1.62 ; \mathrm{I}^{2}=91.9 \% ; \mathrm{P}<0.05\right)$ [28], and Prasad, $\mathrm{M}$. found that for

mobile phone use of 10 years or longer (or $>1640 \mathrm{~h}$ ), the overall result of the meta-analysis showed a 1.33 times increase in risk [27]. Nevertheless, the INTERPHONE Study Group found no significant association between long-term mobile use and the risk of glioma (OR, 1.49; $95 \% \mathrm{Cl}, 0.80-2.78 ;$ I $\left.^{2}=91.5 \%\right)$ [9]. But their result showed significant heterogeneity, so whether the result was credible enough should be considered. Study quality and source of funding could also influence the research outcomes [27]. Thus, larger and longer studies are required to better characterize this possible link: the dose-response relationship exist between mobile/cellular phone use. It is known that there are biological differences between low-grade glioma and high grade-glioma. Low-grade glioma, with a long latency period, is potentially more vulnerable to radiation from mobile phones, While high-grade disease has a short latency period [29]. As the knowledge of key molecular alterations that provided superior prognostication related to glioma developed fast [30], the linkage between mobile phone usage and glioma risk should be further investigated and discussed.

Our results also showed that regular use of mobile phones is associated with the risk of meningioma (OR: $\left.0.84,95 \% \mathrm{Cl}: 0.78-0.91, \mathrm{I}^{2}=47.3 \%, \mathrm{p}=0.091\right)$. When the subgroup analysis of the duration of mobile/cellular phone use was performed, it was found that the impact of short-term and medium-term mobile/cellular phone use on the risk of meningioma was statistically significant (OR: $0.83,95 \% \mathrm{Cl}: 0.76-0.90, \mathrm{I}^{2}=39.5 \%, \mathrm{p}=0.142$ and $\mathrm{OR}$ : $0.83,95 \% \mathrm{Cl}$ : 0.75 $0.93, \mathrm{I}^{2}=32.3 \%, \mathrm{p}=0.194$, respectively), but not for long-term mobile/cellular phone use (OR: $\left.0.91,95 \% \mathrm{Cl}: 0.80-1.03, \mathrm{l}^{2}=0.0 \%, \mathrm{p}=0.870\right)$. Hardell L., et al. (2008) conducted a meat-analysis on the regular use and long-term use of mobile/cellular phone, results of which are consistent with ours (OR: 0.8, 95\%Cl: 0.7-0.99 and OR: 1.3, 95\% Cl: 0.9-1.8, respectively), but there is no relevant analyses on short-term and median-term [31]. Lahkola A., et al. (2006) meta-analyzed the longest use of mobile phones of included articles, but found no statistically significant correlation (OR: $0.87,95 \% \mathrm{Cl}: 0.72-1.05)$ [32]

Meningioma can cause epilepsy and neurological deficits caused by compression of adjacent nerve tissues through progressive enlargement, which is the most common tumor originating in the meninges [33]. The contribution of mobile/cellular phone use to the risk of meningioma may need to consider the 
synergistic effect of metal and RF-EMF. The correlation between radiation exposure and meningioma risk may be more affected by the age at the time of radiation exposure than the amount of exposure [34]. Considering that the latency period from radiation exposure to meningioma occurrence can be as long as 36 years [35], the definition of long-time exposure for meningiomas in the current researches is still not appropriate. Moreover, RF-EMF based on occupational exposure has not been shown to be associated with an increased risk of meningioma [36, 37]. The current evidence concerning the risk of meningioma and the use of mobile/cellular phones is relatively limited, and more long-term studies with large samples are still urgently needed.

In this meta-analysis, there was no statistically significant association between regualr use of mobile/cellular phone and acoustic neuroma (OR, 0.98 ; $95 \% \mathrm{Cl}$, $\left.0.76-1.25 ; l^{2}=60.7 \%, p=0.013\right)$. When it comes to subgroup analysis, the impact of duration of use still has no statistical significance. There are also a few of meta-analysis studied acoustic neuroma. In 2008, L. Hardell published meta-analysis of nine studies on acoustic neuroma and yield (OR, 0.9; 95\% $\mathrm{Cl}, 0.7-1.1)$

. But when it comes to use $>$ or $=10$ years, the result showed positive effect on using mobile phone to the risk of acoustic neuroma (OR, 1.3; 05\% $\mathrm{Cl}, 0.6-2.8)$ [32]. However, they did not analysis the risk for all tumors. A. Bortkiewicz' s meta-analysis in 2017 showed similar result as ours (OR, 0.96; 95\% Cl, 0.87-1.06), but they did not study the duration of using mobile phone and the risk of acoustic neuroma [38].

The followings are several limitations that may contribute to the result. Selection bias is a concern that the cases and controls may not be representative. For example, cases may be under ascertainment for the reason that they were diagnosed and treated outside study area or in some not-participating clinics. Also, people who use mobile phone regularly may have higher potential to participate, especially when the questionnaire is computer-assisted. Thus if mobile/cellular phone users in the control groups were more likely to participate than non-users, the risk may be underestimated. And few of the studies did not use blinding at interview. What should be noticed is that the dead who died of serious conditions were excluded and only survivals participated, which may also affect the result. What's more, the number of studies in the meta-analysis is small, especially when it comes to subgroup analysis.

In conclusion, our study performed a meta-analysis on the association between mobile/cellular phone use and risk of gioma, meningioma and acoustic neuroma based on the duration of use. We found use of mobile phone can decrease the risk of meningioma, especially when the time since first use was between 0-5 years and 5-10 years, while the protective effect disappeared in longer term (more than 10/11 years). For glioma and acoustic neuroma, there were no statistical significance in our meta-analysis. More studies and more cases are needed to explore the possible influence of long-term use of mobile phone, and one standard protocol is also needed for large scale research.

\section{Declarations}

\section{Statements \& Declarations}

\section{Funding}

The authors declare that no funds, grants, or other support were received during the preparation of this manuscript.

\section{Competing Interests}

The authors have no relevant financial or non-financial interests to disclose.

\section{Author Contributions:}

All authors contributed to the study conception and design.

1. Conception and design: Yu-Xin Feng;

2. Administrative support: Ying Wang;

3. Provision of study materials or patients:Ying Wang;

4. Collection and assembly of data: Yu-Xin Feng, Zhi-Ru Zhou, Quan-Ming Fei;

5. Data analysis and interpretation: Yu-Xin Feng, Zhi-Ru Zhou, Quan-Ming Fei;

6. Manuscript writing: All authors;

7. Final approval of manuscript: All authors

\section{Data Availability}

The datasets generated during and/or analysed during the current study are available from the corresponding author on reasonable request.

\section{Acknowledgement}

We would like to thank Yao Lu, the Third Xiangya Hospital of Central South University, for her support of this study.

\section{Ethical Statement}

The authors are accountable for all aspects of the work in ensuring that questions related to the accuracy or integrity of any part of the work are appropriately investigated and resolved.

\section{References}


1. Dasdag S, Akdag MZ. The link between radiofrequencies emitted from wireless technologies and oxidative stress. J Chem Neuroanat. 2016;75(Pt B):8593. https://doi.org/10.1016/j.jchemneu.2015.09.001

2. Kesari KK, Agarwal A, Henkel R. Radiations and male fertility. Reprod Biol Endocrinol. 2018;16(1):118. https://doi.org/10.1186/s12958-018-0431-1

3. Baan R, Grosse Y, Lauby-Secretan B, et al. Carcinogenicity of radiofrequency electromagnetic fields [published correction appears in Lancet Oncol. 2015 Aug;16(8):e379]. Lancet Oncol. 2011;12(7):624-626. https://doi.org/10.1016/s1470-2045(11)70147-4

4. Carlberg M, Hardell L. Evaluation of Mobile Phone and Cordless Phone Use and Glioma Risk Using the Bradford Hill Viewpoints from 1965 on Association or Causation. Biomed Res Int. 2017;2017:9218486. https://doi.org/10.1155/2017/9218486

5. de Siqueira EC, de Souza FTA, Gomez RS, Gomes CC, de Souza RP. Does cell phone use increase the chances of parotid gland tumor development? A systematic review and meta-analysis. J Oral Pathol Med. 2017;46(7):480-483. https://doi.org/10.1111/jop.12531

6. Repacholi MH, Lerchl A, Röösli M, et al. Systematic review of wireless phone use and brain cancer and other head tumors. Bioelectromagnetics. 2012;33(3):187-206. https://doi.org/10.1002/bem.20716

7. Hardell L, Carlberg M, Söderqvist F, et al. Case-control study of the association between malignant brain tumours diagnosed between 2007 and 2009 and mobile and cordless phone use. Int J Oncol. 2013;43(6):1833-1845. https://doi.org/10.3892/ijo.2013.2111

8. Hardell L, Carlberg M, Söderqvist F, et al. Long-term use of cellular phones and brain tumours: increased risk associated with use for $>$ or $=10$ years. Occup Environ Med. 2007;64(9):626-632. https://doi.org/10.1136/oem.2006.029751

9. INTERPHONE Study Group. Brain tumour risk in relation to mobile telephone use: results of the INTERPHONE international case-control study [published correction appears in Int J Epidemiol. 2012 Feb;41(1):328. Montestruq, L [corrected to Montestrucq, L]]. Int J Epidemiol. 2010;39(3):675694. https://doi.org/10.1093/ije/dyq079

10. Schüz J, Böhler E, Berg G, et al. Cellular phones, cordless phones, and the risks of glioma and meningioma (Interphone Study Group, Germany). Am J Epidemiol. 2006;163(6):512-520. https://doi.org/10.1093/aje/kwj068

11. Lönn S, Ahlbom A, Hall P, et al; Swedish Interphone Study Group. Long-term mobile phone use and brain tumor risk. Am J Epidemiol. 2005;161(6):526535. https://doi.org/10.1093/aje/kwi091

12. Lahkola A, Salminen T, Raitanen J, et al. Meningioma and mobile phone use-a collaborative case-control study in five North European countries. Int $J$ Epidemiol. 2008;37(6):1304-1313. https://doi.org/10.1093/aje/kwi091

13. Coureau G, Bouvier G, Lebailly P, et al. Mobile phone use and brain tumours in the CERENAT case-control study. Occup Environ Med. 2014;71(7):514522. https://doi.org/10.1136/oemed-2013-101754

14. Carlberg M, Hardell L. Pooled analysis of Swedish case-control studies during 1997-2003 and 2007-2009 on meningioma risk associated with the use of mobile and cordless phones. Oncol Rep. 2015;33(6):3093-3098. https://doi.org/10.3892/or.2015.3930

15. Lahkola A, Auvinen A, Raitanen J, et al. Mobile phone use and risk of glioma in 5 North European countries. Int J Cancer. 2007;120(8):17691775. https://doi.org/10.1002/ijc.22503

16. Hardell L, Carlberg M. Mobile phone and cordless phone use and the risk for glioma - Analysis of pooled case-control studies in Sweden, $1997-2003$ and 2007-2009. Pathophysiology. 2015;22(1):1-13. https://doi.org/10.1016/j.pathophys.2014.10.001

17. Hepworth SJ, Schoemaker MJ, Muir KR, et al. Mobile phone use and risk of glioma in adults: case-control study. BMJ. 2006;332(7546):883887. https://doi.org/10.1136/bmj.38720.687975.55

18. Klaeboe L, Blaasaas KG, Tynes T. Use of mobile phones in Norway and risk of intracranial tumours. Eur J Cancer Prev. 2007;16(2):158164. https://doi.org/10.1097/01.cej.0000203616.77183.4c

19. INTERPHONE Study Group. Acoustic neuroma risk in relation to mobile telephone use: results of the INTERPHONE international case-control study. Cancer Epidemiol. 2011;35(5):453-464. https://doi.org/10.1016/j.canep.2011.05.012

20. Christensen HC, Schüz J, Kosteljanetz M, et al. Cellular telephone use and risk of acoustic neuroma. Am J Epidemiol. 2004;159(3):277283. https://doi.org/10.1093/aje/kwh032

21. Hardell L, Näsman A, Påhlson A, et al. Use of cellular telephones and the risk for brain tumours: A case-control study. Int J Oncol. 1999;15(1):113116. https://doi.org/10.3892/ijo.15.1.113

22. Hardell L, Carlberg M, Söderqvist F, et al. Pooled analysis of case-control studies on acoustic neuroma diagnosed 1997-2003 and 2007-2009 and use of mobile and cordless phones. Int J Oncol. 2013;43(4):1036-1044. https://doi.org/10.3892/ijo.2013.2025

23. Schlehofer B, Schlaefer K, Blettner M, et al. Environmental risk factors for sporadic acoustic neuroma (Interphone Study Group, Germany). Eur J Cancer. 2007;43(11):1741-1747. https://doi.org/10.1016/j.ejca.2007.05.008

24. Pettersson D, Mathiesen T, Prochazka M, et al. Long-term mobile phone use and acoustic neuroma risk. Epidemiology. 2014;25(2):233241. https://doi.org/10.1097/EDE.0000000000000058

25. Lönn S, Ahlbom A, Hall P, et al. Mobile phone use and the risk of acoustic neuroma. Epidemiology. 2004;15(6):653659. https://doi.org/10.1097/01.ede.0000142519.00772.bf

26. Kan P, Simonsen SE, Lyon JL, et al. Cellular phone use and brain tumor: a meta-analysis. J Neurooncol. 2008;86(1):7178. https://doi.org/10.1007/s11060-007-9432-1

27. Prasad M, Kathuria P, Nair P, et al. Mobile phone use and risk of brain tumours: a systematic review of association between study quality, source of funding, and research outcomes. Neurol Sci. 2017;38(5):797-810. https://doi.org/10.1007/s10072-017-2850-8

28. Wang Y, Guo X. Meta-analysis of association between mobile phone use and glioma risk. J Cancer Res Ther. 2016;12(Supplement):C298C300. https://doi.org/10.4103/0973-1482.200759

Page 6/15 
29. Yang M, Guo W, Yang C, et al. Mobile phone use and glioma risk: A systematic review and meta-analysis. PLoS One. 2017;12(5):e0175136. Published 2017 May 4. https://doi.org/10.1371/journal.pone.0175136

30. Tom MC, Cahill DP, Buckner JC, et al. Management for Different Glioma Subtypes: Are All Low-Grade Gliomas Created Equal?. Am Soc Clin Oncol Educ Book. 2019;39:133-145. https://doi.org/10.1200/EDBK_238353

31. Hardell L, Carlberg M, Söderqvist F, et al. Meta-analysis of long-term mobile phone use and the association with brain tumours. Int $J$ Oncol. 2008;32(5):1097-1103. https://doi.org/10.3892/ijo.32.5.1097

32. Lahkola A, Tokola K, Auvinen A. Meta-analysis of mobile phone use and intracranial tumors. Scand J Work Environ Health. 2006;32(3):171177. https://doi.org/10.5271/sjweh.995

33. Whittle IR, Smith C, Navoo P, et al. Meningiomas. Lancet. 2004;363(9420):1535-1543. https://doi.org/10.1016/S0140-6736(04)16153-9

34. Phillips LE, Frankenfeld CL, Drangsholt M, et al. Intracranial meningioma and ionizing radiation in medical and occupational settings. Neurology. 2005;64(2):350-352. https://doi.org/10.1212/01.WNL.0000149766.65843.19

35. Sadetzki S, Flint-Richter P, Ben-Tal T, et al. Radiation-induced meningioma: a descriptive study of 253 cases. J Neurosurg. 2002;97(5):10781082. https://doi.org/10.3171/jns.2002.97.5.1078

36. Baldi I, Coureau G, Jaffré A, et al. Occupational and residential exposure to electromagnetic fields and risk of brain tumors in adults: a case-control study in Gironde, France. Int J Cancer. 2011;129(6):1477-1484. https://doi.org/10.1002/ijc.25765

37. Berg G, Spallek J, Schüz J, et al. Occupational exposure to radio frequency/microwave radiation and the risk of brain tumors: Interphone Study Group, Germany. Am J Epidemiol. 2006;164(6):538-548. https://doi.org/10.1093/aje/kwj247

38. Bortkiewicz A, Gadzicka E, Szymczak W. Mobile phone use and risk for intracranial tumors and salivary gland tumors - A meta-analysis [published correction appears in Int J Occup Med Environ Health. 2017 Jun 19;30(4):685]. Int J Occup Med Environ Health. 2017;30(1):27-

43. https://doi.org/10.13075/ijomeh.1896.00802

\section{Tables}

Table 1. General characteristics of studies included in the meta-analysis 


\begin{tabular}{|c|c|c|c|c|c|c|c|c|c|}
\hline $\begin{array}{l}1 \text { st auther, } \\
\text { Year of } \\
\text { publication }\end{array}$ & $\begin{array}{l}\text { Study } \\
\text { period }\end{array}$ & Country & $\begin{array}{l}\text { Type of } \\
\text { cancer }\end{array}$ & Sex (Age) & Score & $\begin{array}{l}\text { Sample } \\
\text { size } \mathrm{Ca} / \mathrm{Co}\end{array}$ & $\begin{array}{l}\text { Type of } \\
\text { phones } \\
\text { used in } \\
\text { analysis }\end{array}$ & $\begin{array}{l}\text { Adjusted } \\
\text { OR from } \\
\text { manuscript } \\
(95 \% \mathrm{Cl})\end{array}$ & Adjustments \\
\hline $\begin{array}{l}\text { E.Cardis } \\
(2010)(9)\end{array}$ & $\begin{array}{l}2000- \\
2004\end{array}$ & $\begin{array}{l}\text { Australia, } \\
\text { Canada, } \\
\text { Denmark, Finland, } \\
\text { France, Germany, } \\
\text { Israel, } \\
\text { Italy, Japan, New } \\
\text { Zealand, Norway, } \\
\text { Sweden and the } \\
\text { UK }\end{array}$ & Meningiomas & $M+F(30-59)$ & 8 & $2708 / 2972$ & Mobile & $\begin{array}{l}0.81(0.7- \\
0.94)\end{array}$ & $\begin{array}{l}\text { Sex, age, } \\
\text { study centre, } \\
\text { ethnicity in } \\
\text { Israel and } \\
\text { education }\end{array}$ \\
\hline \multirow[t]{2}{*}{$\begin{array}{l}\text { J.Schuz } \\
(2006)(10)\end{array}$} & $\begin{array}{l}2000- \\
2003\end{array}$ & France & Gliomas & $M+F(30-59)$ & 8 & $366 / 732$ & Cellular & $\begin{array}{l}0.98(0.74- \\
1.29)\end{array}$ & \multirow{2}{*}{$\begin{array}{l}\text { Educational } \\
\text { level, } \\
\text { disposable } \\
\text { income, and } \\
\text { marital } \\
\text { status }\end{array}$} \\
\hline & & & Meningiomas & & & $381 / 762$ & & $\begin{array}{l}0.84(0.62- \\
1.13)\end{array}$ & \\
\hline \multirow[t]{2}{*}{$\begin{array}{l}\text { S.Lönn } \\
(2005)(11)\end{array}$} & $\begin{array}{l}2000- \\
2002\end{array}$ & Sweden & Gliomas & $M+F(20-69)$ & 8 & $371 / 674$ & Mobile & $\begin{array}{l}0.8(0.6- \\
1.0)\end{array}$ & \multirow{2}{*}{$\begin{array}{l}\text { Age, gender, } \\
\text { geographic } \\
\text { region, and } \\
\text { education }\end{array}$} \\
\hline & & & Meningiomas & & & $273 / 674$ & & $\begin{array}{l}0.7(0.5- \\
0.9)\end{array}$ & \\
\hline $\begin{array}{l}\text { A.Lahkola } \\
(2008)(12)\end{array}$ & $\begin{array}{l}2000- \\
2004\end{array}$ & $\begin{array}{l}\text { Denmark, Finland, } \\
\text { Norway, Sweden } \\
\text { and the United } \\
\text { Kingdom }\end{array}$ & Meningiomas & $\begin{array}{l}M+F(20-69 \text { years in } \\
\text { the Nordic countries } \\
\text { and } 18-59 \text { years in } \\
\text { Southeast England) }\end{array}$ & 7 & $1204 / 2945$ & Mobile & $\begin{array}{l}0.76(0.65- \\
0.89)\end{array}$ & $\begin{array}{l}\text { Sex, five-year } \\
\text { age group, } \\
\text { region and } \\
\text { country }\end{array}$ \\
\hline \multirow[t]{2}{*}{$\begin{array}{l}\text { G.Coureau } \\
(2014)(13)\end{array}$} & $\begin{array}{l}2005- \\
2008\end{array}$ & France & Gliomas & $M+F(\geq 16)$ & 8 & $253 / 504$ & Mobile & $\begin{array}{l}0.90(0.61- \\
1.34)\end{array}$ & \multirow{2}{*}{$\begin{array}{l}\text { Level of } \\
\text { education } \\
\text { and ionising } \\
\text { radiation } \\
\text { exposure }\end{array}$} \\
\hline & & & Meningiomas & & & $194 / 388$ & & $\begin{array}{l}1.24(0.86- \\
1.77)\end{array}$ & \\
\hline $\begin{array}{l}\text { M.Carlberg } \\
(2015)(14)\end{array}$ & $\begin{array}{l}1997- \\
2003 \\
\text { and } \\
2007- \\
2009\end{array}$ & Sweden & Meningiomas & $\begin{array}{l}\text { M+F (20-80 (1997- } \\
2003), 18-75 \text { (2007- } \\
2009)\end{array}$ & 8 & $956 / 2148$ & Mobile & $\begin{array}{l}1.0(0.9- \\
1.2)\end{array}$ & $\begin{array}{l}\text { Age at } \\
\text { diagnosis, } \\
\text { gender, SEl- } \\
\text { code and } \\
\text { year of } \\
\text { diagnosis }\end{array}$ \\
\hline $\begin{array}{l}\text { A.Lahkola } \\
(2007)(15)\end{array}$ & $\begin{array}{l}2000- \\
2004\end{array}$ & $\begin{array}{l}\text { Denmark, Finland, } \\
\text { Norway, Sweden, } \\
\text { Southeast } \\
\text { England }\end{array}$ & Gliomas & $M+F(18-69)$ & 7 & $1521 / 3301$ & Mobile & $\begin{array}{l}0.78(0.68- \\
0.91)\end{array}$ & $\begin{array}{l}\text { Use of } \\
\text { hands-free } \\
\text { devices }\end{array}$ \\
\hline $\begin{array}{l}\text { L.Hardell } \\
(2015)(16)\end{array}$ & $\begin{array}{l}1997- \\
2003 \\
\text { and } \\
2007- \\
2009\end{array}$ & Sweden & Gliomas & $M+F(20-80)$ & 8 & $1380 / 3530$ & Mobile & $\begin{array}{l}1.3(1.1- \\
1.6)\end{array}$ & $\begin{array}{l}\text { Age at } \\
\text { diagnosis, } \\
\text { gender, SEl- } \\
\text { code, and } \\
\text { year for } \\
\text { diagnosis }\end{array}$ \\
\hline $\begin{array}{l}\text { Sarah J } \\
\text { Hepworth } \\
(2006)(17)\end{array}$ & $\begin{array}{l}2000- \\
2004\end{array}$ & England & Gliomas & $M+F(18-69)$ & 7 & $966 / 1716$ & Mobile & $\begin{array}{l}0.94(0.78- \\
1.13)\end{array}$ & $\begin{array}{l}\text { Age at } \\
\text { reference } \\
\text { date (in } 5 \\
\text { year age } \\
\text { groups), sex, } \\
\text { region, } \\
\text { Townsend } \\
\text { deprivation } \\
\text { category, } \\
\text { and } \\
\text { interview } \\
\text { reference } \\
\text { date } \\
\text { category }\end{array}$ \\
\hline $\begin{array}{l}\text { L.Klaeboe } \\
(2007)(18)\end{array}$ & $\begin{array}{l}2001- \\
2002\end{array}$ & Norway & $\begin{array}{l}\text { Acoustic } \\
\text { neuromas }\end{array}$ & $M+F(16-69)$ & 7 & $45 / 358$ & Mobile & $\begin{array}{l}0.5(0.2- \\
1.0)\end{array}$ & $\begin{array}{l}\text { Age, sex, } \\
\text { residential } \\
\text { area and } \\
\text { attained } \\
\text { educational } \\
\text { level }\end{array}$ \\
\hline $\begin{array}{l}\text { E. Cardis } \\
(2011)(19)\end{array}$ & $\begin{array}{l}2000- \\
2004\end{array}$ & $\begin{array}{l}\text { Australia, Canada, } \\
\text { Denmark, Finland, } \\
\text { France, Germany, } \\
\text { Israel, } \\
\text { Italy, Japan, New } \\
\text { Zealand, Norway, } \\
\text { Sweden, and the } \\
\text { UK }\end{array}$ & $\begin{array}{l}\text { Acoustic } \\
\text { neuromas }\end{array}$ & $M+F(30-59)$ & 8 & $1105 / 2145$ & Mobile & $\begin{array}{l}0.85(0.69- \\
1.04)\end{array}$ & $\begin{array}{l}\text { Sex, age, } \\
\text { study centre, } \\
\text { ethnicity in } \\
\text { Israel, and } \\
\text { education }\end{array}$ \\
\hline
\end{tabular}




\begin{tabular}{|c|c|c|c|c|c|c|c|c|c|}
\hline $\begin{array}{l}\text { H. C. } \\
\text { Christensen } \\
(2004)(20)\end{array}$ & $\begin{array}{l}2000- \\
2002\end{array}$ & Denmark & $\begin{array}{l}\text { Acoustic } \\
\text { neuromas }\end{array}$ & $M+F(20-69)$ & 9 & $106 / 212$ & Cellular & $\begin{array}{l}0.90(0.51- \\
1.57)\end{array}$ & $\begin{array}{l}\text { Educational } \\
\text { level, marital } \\
\text { status, use } \\
\text { of hands- } \\
\text { free devices } \\
\text { in vehicles } \\
\text { (ever vs. } \\
\text { never), and } \\
\text { region }\end{array}$ \\
\hline $\begin{array}{l}\text { L. Hardell } \\
(1999)(21)\end{array}$ & \multicolumn{2}{|c|}{$\begin{array}{l}\text { Uppsala-Örebro region } \\
(1994-1996) \\
\text { and Stockholm region } \\
(1995-1996)\end{array}$} & $\begin{array}{l}\text { Acoustic } \\
\text { neuromas }\end{array}$ & $\mathrm{M}+\mathrm{F}$ (mean age:50) & 7 & $209 / 425$ & Cellular & $\begin{array}{l}0.98(0.69- \\
1.41)\end{array}$ & Not reported \\
\hline $\begin{array}{l}\text { L. Hardell } \\
(2013)(22)\end{array}$ & $\begin{array}{l}1997- \\
2003 \\
\text { and } \\
2007- \\
2009\end{array}$ & Sweden & $\begin{array}{l}\text { Acoustic } \\
\text { neuromas }\end{array}$ & $\begin{array}{l}\text { M+F (Ca:23-80/Co:19- } \\
80)\end{array}$ & 7 & $316 / 3530$ & Mobile & $\begin{array}{l}1.6(1.2- \\
2.2)\end{array}$ & $\begin{array}{l}\text { Age at } \\
\text { diagnosis, } \\
\text { gender, SEl- } \\
\text { code and } \\
\text { year of } \\
\text { diagnosis }\end{array}$ \\
\hline $\begin{array}{l}\text { B. } \\
\text { Schlehofer } \\
(2007)(23)\end{array}$ & $\begin{array}{l}2000- \\
2003\end{array}$ & Germany & $\begin{array}{l}\text { Acoustic } \\
\text { neuromas }\end{array}$ & $M+F$ & 8 & $97 / 194$ & Mobile & $\begin{array}{l}0.67(0.38 \\
-1.19)\end{array}$ & $\begin{array}{l}\text { SES, living } \\
\text { area } \\
\text { urban/rural, } \\
\text { age at } \\
\text { diagnosis } \\
\text { and study } \\
\text { centre }\end{array}$ \\
\hline $\begin{array}{l}\text { D. } \\
\text { Pettersson } \\
(2014)(24)\end{array}$ & $\begin{array}{l}2002- \\
2007\end{array}$ & Sweden & $\begin{array}{l}\text { Acoustic } \\
\text { neuromas }\end{array}$ & $M+F(\geq 20)$ & 7 & $422 / 643$ & Mobile & $\begin{array}{l}1.18(0.88- \\
1.59)\end{array}$ & Unadjusted \\
\hline $\begin{array}{l}\text { S. Lönn } \\
(2004)(25)\end{array}$ & $\begin{array}{l}1999- \\
2002\end{array}$ & Sweden & $\begin{array}{l}\text { Acoustic } \\
\text { neuromas }\end{array}$ & $M+F(20-69)$ & 8 & $148 / 604$ & Mobile & $\begin{array}{l}1.0(0.6- \\
1.5)\end{array}$ & $\begin{array}{l}\text { Age, sex, } \\
\text { residential } \\
\text { area, } \\
\text { and } \\
\text { educational } \\
\text { level }\end{array}$ \\
\hline
\end{tabular}

Table 2. Quality assessment 
Adequate Representativeness Selection Definition Definition

of of Patient Cases

Patient

Cases

$\begin{array}{ll}\text { Selection Definition } \\ \text { of } & \text { of } \\ \text { Controls } & \text { Controls }\end{array}$

Ascertainment Same Method Nonof Response

Ascertainment Rate

Ascertainment

\section{Acoustic neuroma}

L.Klaeboe(2007)

(18)

E. Cardis(2011)

(19)

H. C.

Christensen(2004)

(20)

L. Hardell(1999)

(21)

L. Hardell(2013)

(22)

B.

(23)

D.

Pettersson(2014)

(24)

S. Lönn(2004)(25)

1

$\begin{array}{lll}1 & 1 & 2\end{array}$

$2 \quad 1$

$1 \quad 1$

0

8

Giloma

S. Lönn(2005)(11)

A. Lahkola(2007) 1

(15)

G. Coureau(2014)

(13)

L. Hard

L. Hardell(2015)

1

1

$+2$

$1 \quad 2$

2

1

1

8

Sarah J

Hepworth(2006)

(17)

J.Schuz(2006)

(10)

1

Meningioma

E.Cardis(2010)(9)

J.Schuz(2006)

(10)

S. Lönn(2005)(11)

A.Lahkola(2008)

(12)

G.Coureau(2014)

(13)

M.Carlberg(2015) 1

(14)

\begin{tabular}{ll}
1 & 1 \\
\hline
\end{tabular}

2

1

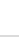

1

8

$\begin{array}{lllll}1 & 1 & 0 & 8\end{array}$

$0 \quad 1$

2

1

1

$0 \quad 7$

$1 \quad 1$

21

1

0

8

\section{Figures}




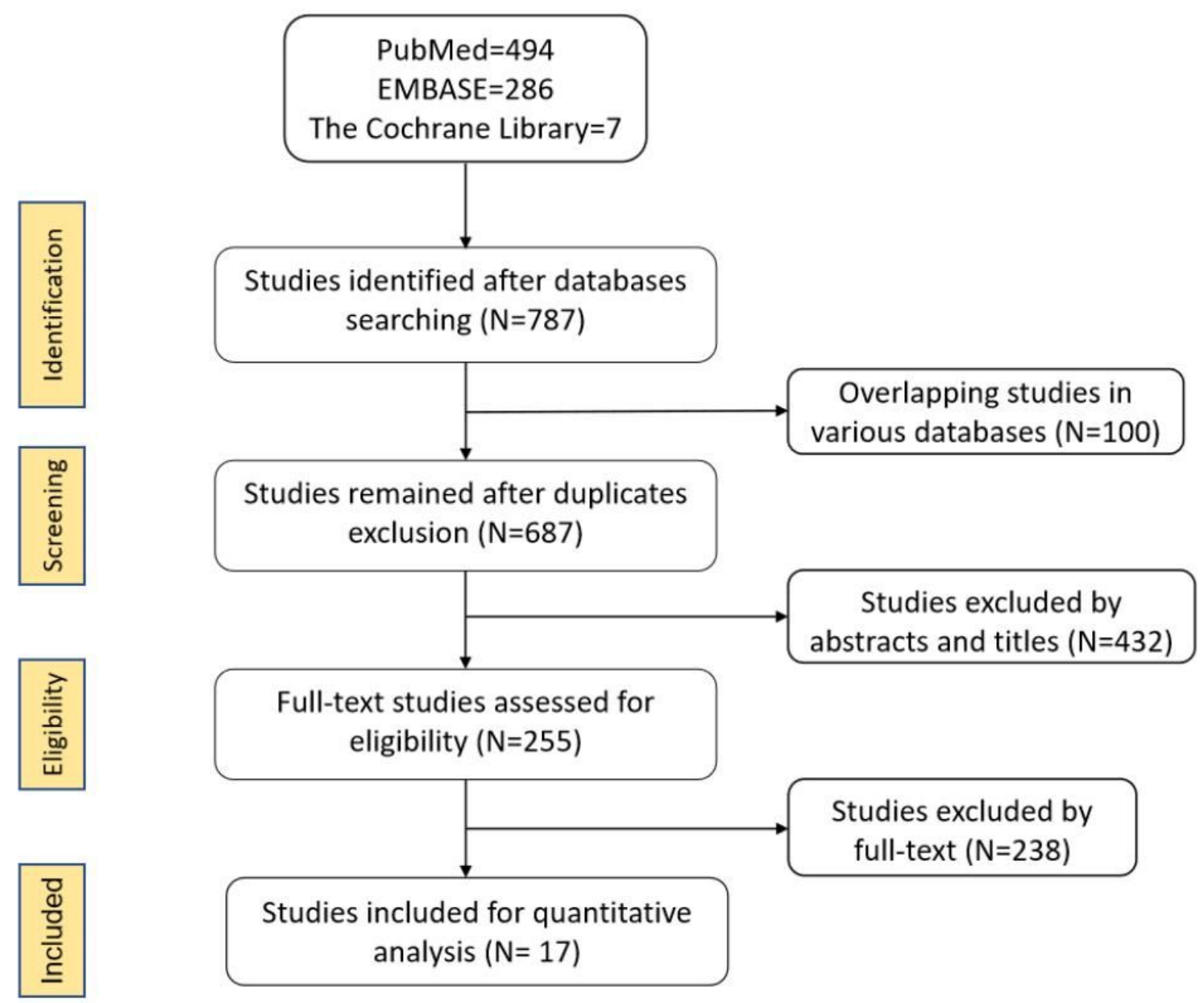

Figure 1

Study selection. 


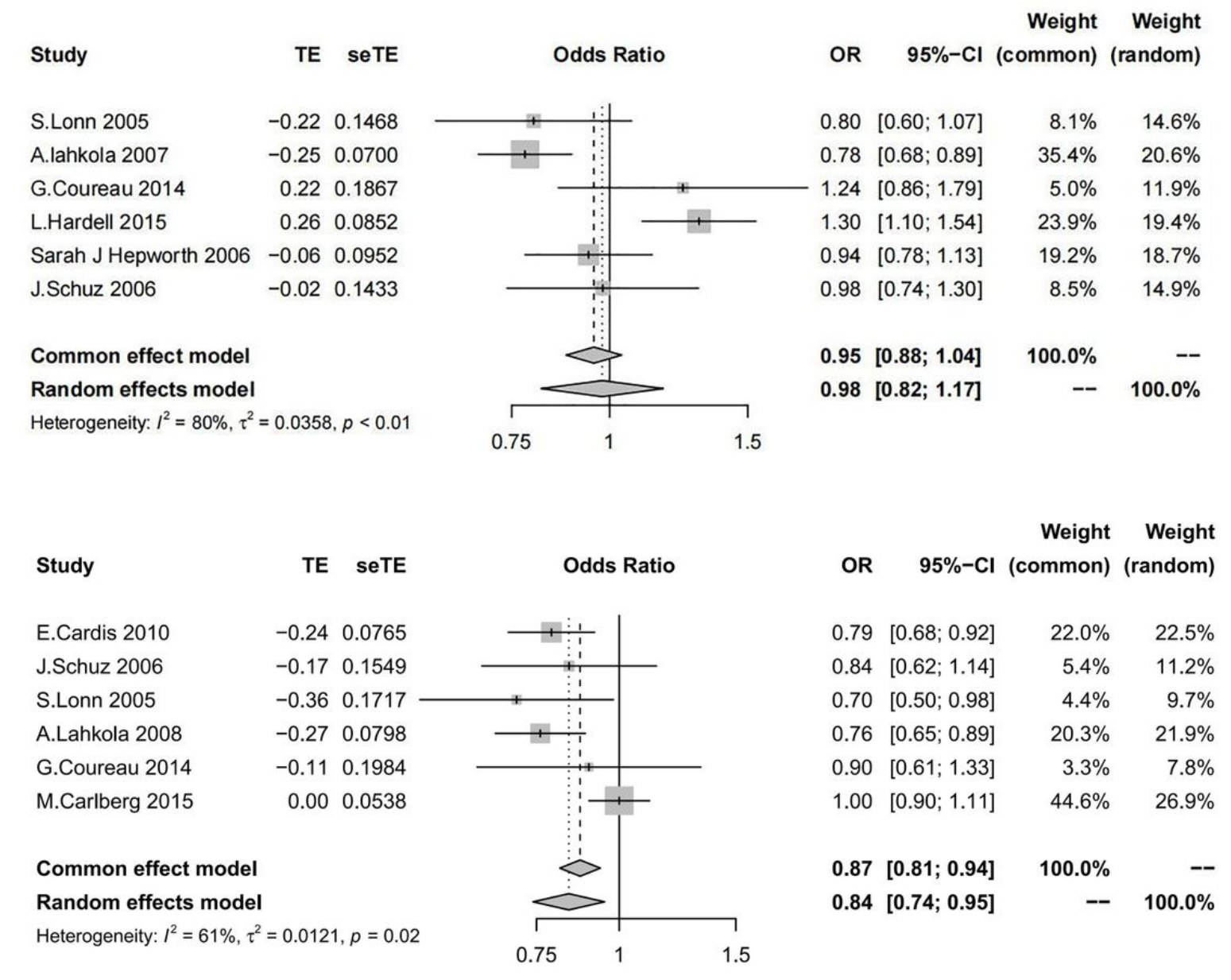

\section{Figure 2}

Mobile/Cellular phone use and risk of gliomas(A), meningiomas(B) and acoustic neuromas(C) in meta-analysis of case-control studies. ES-effect size (odds ratio); $\mathrm{Cl}-$ confidence interval. 


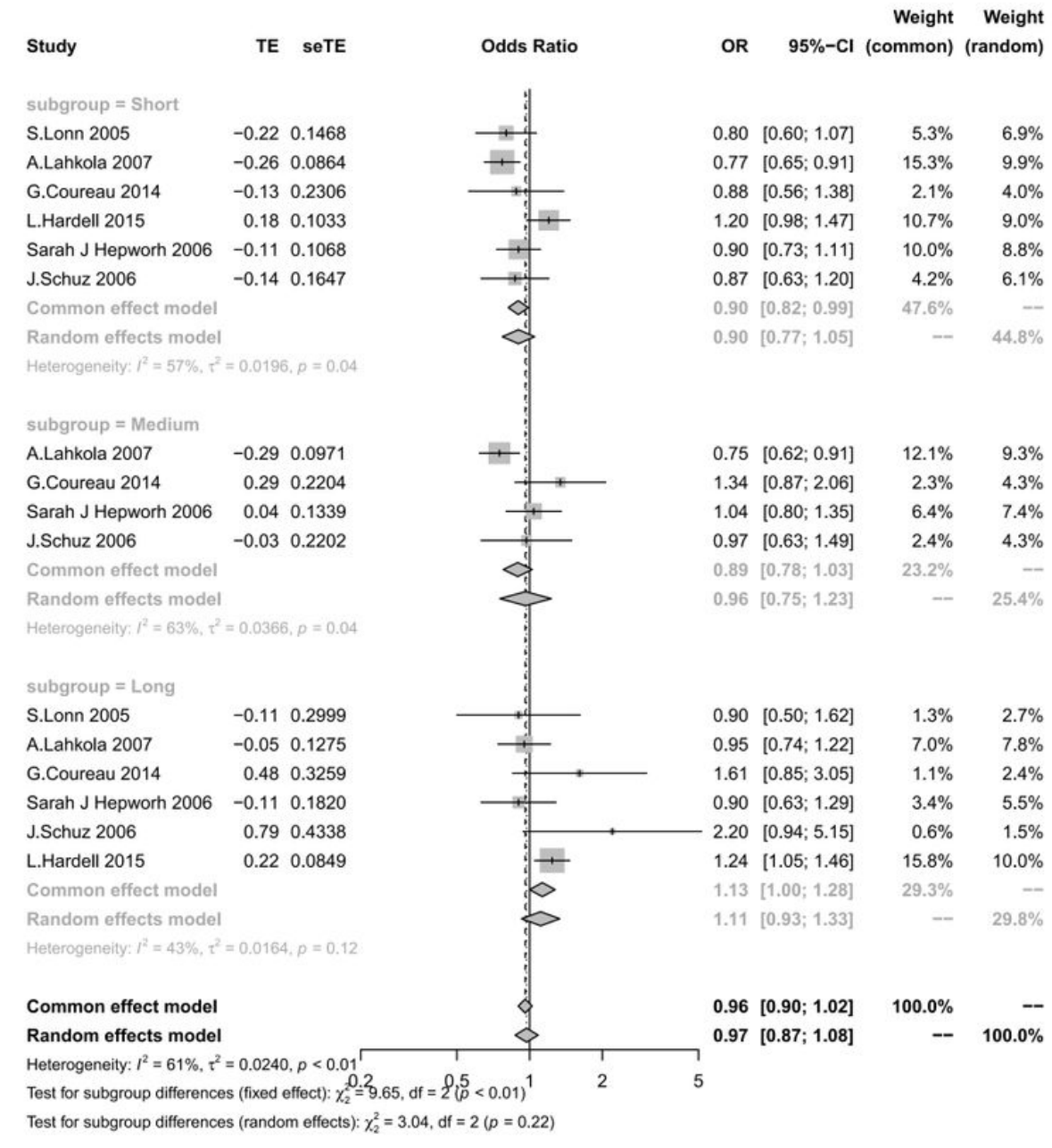

\section{Figure 3}

Mobile/Cellular phone use duration and risk of glioma in subgroup meta-analysis of case-control studies. OR-odds ratio; Cl-confidence interval. 


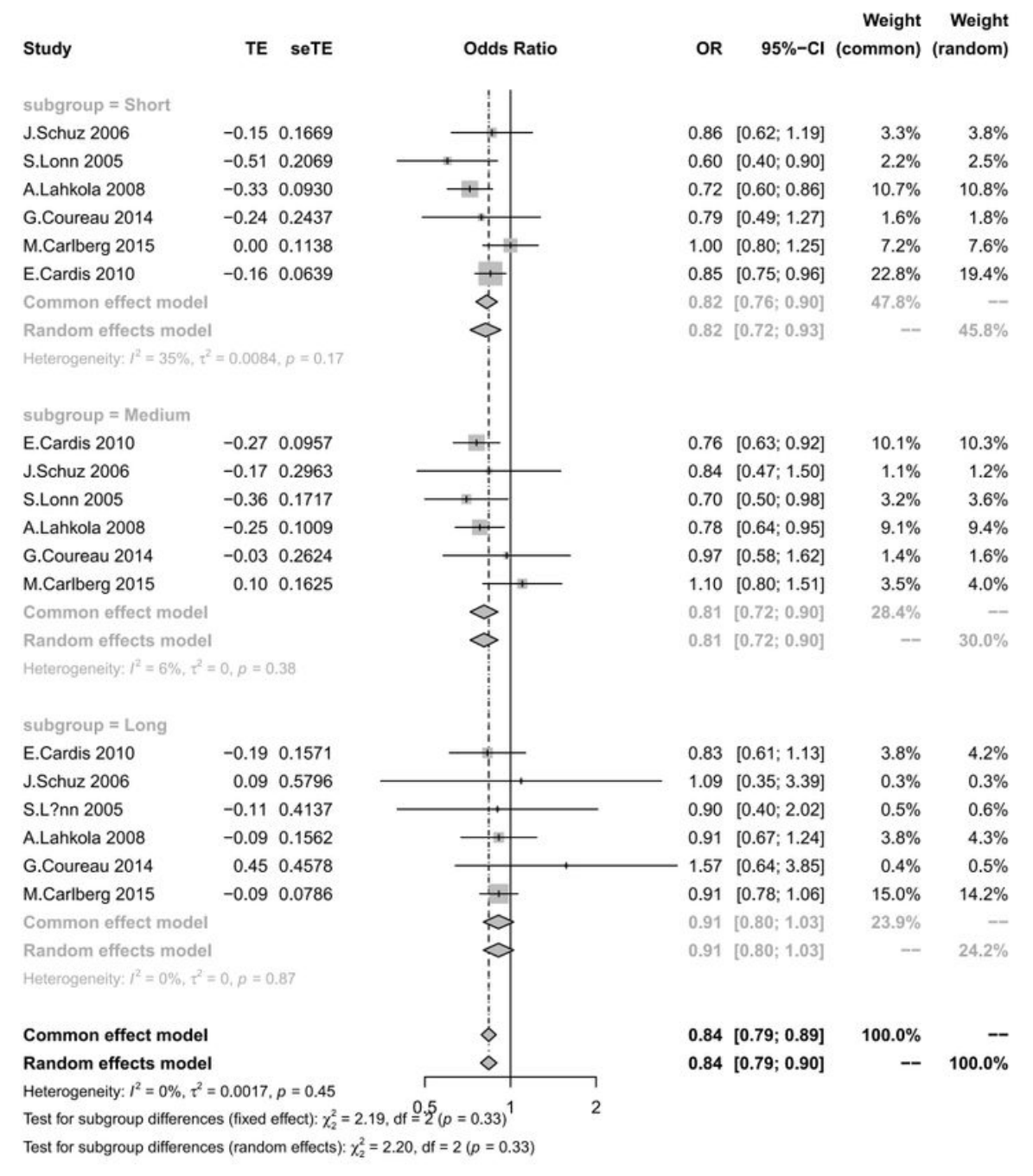

\section{Figure 4}

Mobile/Cellular phone use duration and risk of meningioma in subgroup meta-analysis of case-control studies. OR-odds ratio; $\mathrm{Cl}-\mathrm{Confidence} \mathrm{interval.}$ 


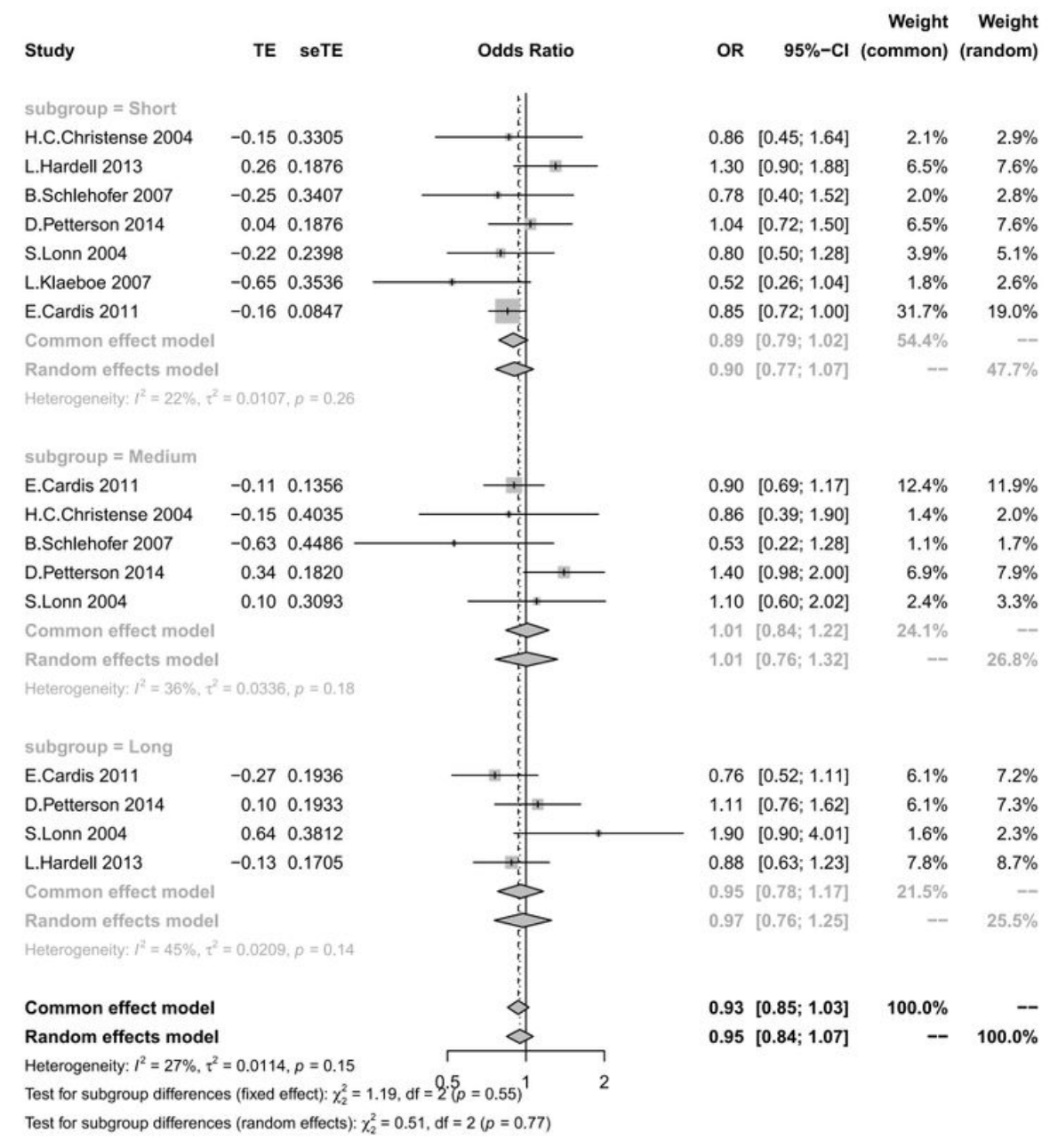

\section{Figure 5}

Mobile/Cellular phone use duration and risk of acoustic neuroma in subgroup meta-analysis of case-control studies. OR-odds ratio; $\mathrm{Cl}-$ confidence interval. 